\title{
Investigating Turkish university students' attitudes towards refugees in a time of Civil War in neighboring Syria
}

\author{
Vezir Aktas $^{1}$ (D) $\cdot$ Yeliz Kındap Tepe ${ }^{2} \cdot$ Roland S. Persson $^{1}$
}

Published online: 27 August 2018

(C) The Author(s) 2018

\begin{abstract}
Thousands of refugees have immigrated to Turkey because of the current Civil War in neighboring Syria. This is causing tensions between refugees and locals. These increasingly negative attitudes towards the incoming victims of conflict are of particular interest. The present study, therefore, aimed at determining the premises of the emergence of such negative attitudes. The research sample consisted of university students who all studied at various faculties at Cumhuriyet University in the Turkish province of Sivas. Data were collected by the Attitude Scale Towards Refugees, the Patriotism Attitude Scale, the Interpersonal Reactivity Index, and the Cirhinlioğlu Religiosity Scale. Data were analyzed by Independent Sample $t$-tests as well as using Stepwise Regression Analyses. Results showed that the feeling of empathy correlated negatively with negative attitudes towards refugees, while blind patriotism, religiosity, and having nationalist/conservative orientations, correlated positively. Men were found to be more negative than women. The feeling of empathy was the most prominent factor in predicting the nature of attitudes towards refugees. Religious doctrine and distancing oneself from conservative and patriotic perspectives appeared to be effective in potentially preventing the development of negative attitudes. In conclusion, research results are discussed in the light of relevant literature.
\end{abstract}

Keywords Attitudes $\cdot$ Refugees $\cdot$ Patriotism $\cdot$ Religiosity $\cdot$ Religiousness $\cdot$ Empathy $\cdot$ Nationalism $\cdot$ Conservatism

The phenomenon of immigration, generally defined as the temporary or permanent movement of individuals or groups from one place to another for a variety reasons (Hagen-Zanker 2008), is likely to have an impact on the demographic, cultural, socio-economic, and psychological characteristics of any society. As the immigration phenomenon is a vast field of research, this study focused on refugees as only one separate aspect of the immigration problem. The research was aimed at identifying factors potentially affecting the attitudes towards refugees in the Turkish Sivas Province. As defined by

Vezir Aktas

vezir.aktas@ju.se

Yeliz Kındap Tepe

yelizkindap@gmail.com

Roland S. Persson

roland.persson@ju.se

1 School of Education and Communication, Jönköping University, Jönköping, Sweden

2 Faculty of Letters, Cumhuriyet University, Sivas, Turkey the United Nations (Bodvarsson and Van den Berg 2013; UN High Commissioner for Refugees [UNHCR] 2011; Wikipedia 2017), a refugee is

a person who has reasonable grounds for fearing oppression because of his or her race, religion, nationality, membership to a specific social group or political views; thus leaving a country of residence and not to return because of fear.

The number of refugees worldwide has been gradually increasing in recent times. Millions leave their ancestral home for reasons of political corruption, war, conflict, or authoritarian regimes consistently violating their human rights. Living in fear because of ethnicity or political views are the main reasons for leaving everything they hold dear behind to seek security elsewhere (Deniz 2014; Doğan et al. 2017).

According to the Global Trends Report of 2016 (UN High Commissioner for Refugees [UNHCR] 2017, 19 June) the number of people globally who were displaced for reason of oppression, conflict, violence or persecution was 59.5 million in 2014. This number increased to 65.3 million a year later, 
and increased even more to 65.6 million by the end of 2016 . Not surprisingly, the refugee problem is one of the most pressing political issues of our time.

Turkey has been regarded as a country of both reception and transit for refugees because of its geographical proximity to Syria. Turkey has been subject to international immigration for asylum seekers, refugees, and transit immigrants, for a long time. However, Turkey has also served as a goal for illegal labor, since the Turkish economy has been more affluent and better organized in comparison to neighboring countries troubled by social and political conflict (İçduygu and Aksel 2012; Güneș 2013). The current Syrian Civil War has caused a tremendous increase in refugee influx. By the end of 2016 Turkey had become host to 2.9 million refugees, the majority of whom had escaped from the Syrian Civil War (UNHCR 2017, 19 June). According to the European Commission (2017, December 11) there are currently more than 3.4 million refugees registered in Turkey of different ethnicities originating in Syrian, Iraq, Afghanistan, Iran, Somalia, and from elsewhere. In comparison, Turkish census data for 2016 published by the Turkish Statistical Institute [TIS] this substantial number of refugees roughly equals the population of 17 medium-sized Turkish cities. No other country currently hosts more refugees than Turkey. Needless to say, this has been commented on in Turkish media. With the increase of number of refugees, they argue, there is also an increase in violence against the refugees. There have for example been reports of alarming tensions in Ankara in 2017 as well as of fighting in Beyșehir in 2016 (Girit 2015). Skirmishes between locals and Syrians in the Hatay Province in 2013 were also made headline news (Yolcu 2014).

The higher the number of refugees in a country the more important it is to understand how to possibly prevent negative attitudes leading to discrimination, hate crime, social exclusion and, as shown, also to increasing conflict between the local population and incoming refugees (Deniz 2014; Doğan et al. 2017). Integration, however, is a complex process. Bringing different cultures together is a two-edged sword. On the one hand, contact and familiarization is possible as well as desirable to achieve. But, on the other hand, it is also ground for possible conflict. Refugees and settled citizens are made to share the same available economic means and opportunities. When these become increasingly scarce rivalry ensues. This, in turn, is likely to generate conflicts of interest, prejudice, alienation, and xenophobia (e.g., Stephan, Ybarra $\&$ Bachman, 1999). Over a longer period of time such tension may also develop into national security threats, which have much wider ramifications in terms of affecting political, economic, and socio-cultural structures, adversely (Lohrmann, 2003; Türkoğlu 2011).

Several studies on immigration and integration emphasize that both xenophobia and ethnic discrimination add to the complexity of the integration process. They contribute to making the situation for already troubled and emotionally exhausted refugees even worse (Aktaş and Persson 2017; Bunar 2007; De los Reyes 2008; Lemaitre 2007; Rydgren 2004). It is a reasonable assumption to make, therefore, that the negative attitudes of local citizens towards refugees is an important and worthwhile study.

The psychological processes, and emotional responses in particular, to unexpected hostility upon arrival to an assumed safe haven has been pursued as a special field of research in recent years. Most studies point towards the ability to empathize as a key mechanism to muster necessary support for settling refugees (Newman et al. 2015; Sirin et al. 2016; Verkuyten et al. 2017). Empathy in this research is generally defined as the emotional and cognitive ability to vicariously understand the observed experiences and emotional situations of others (Davis 1983). This definition describes an another-oriented feeling. It contributes to developing positive social behavior and, importantly, also lessens aggressive behavior (Anderson et al. 2010; Carreras et al. 2014; Greitemeyer 2011; Tamura and Sugiura 2017). In addition, many studies stress the significance of empathy in defusing conflicts between groups (Dovidio et al. 2010; Eisenberg et al. 2010). Individuals capable of a high level of empathy generally make an intentional effort to eliminate the worries of refugees (Eisenberg \& Fabes, 1998; Murphy at el. 1999). In line with the current research field, therefore, we are assuming that the degree to which people understand the refugee predicament will also correlate with their measured level of empathy. This, too, has been shown to be significant in determining attitudes towards refugees. There exists, however, research which has suggested that attitudes also correlate with individual characteristics such as gender, age, level of education, political leanings, religious convictions, and patriotism. For example, men tend to be more negative towards refugees than women are (Bentsen 2017; Bloom 2011; Hernes and Knudsen 1992; Short 2004). A few studies suggest that age does not correlate with such attitudes (e.g., Short 2004), whereas other studies have concluded either the opposite (e.g., Hernes and Knudsen 1992), or that there is a negative correlation between age group and a positive attitude towards refugees (e.g., Bentsen 2017; Bloom 2011; Gorodzeisky and Semyonov 2009). On the other hand, studies focusing on the relationship between level of education, political views and attitudes, have generally concluded that negative attitudes towards refugees show a tendency to decrease as the level of education increases (Billiet 1995; Bloom 2011; Hainmueller and Hiscox 2007; Hernes and Knudsen 1992; Jolly and DiGiusto 2014; Paas and Halapuu 2012). Also, individuals adhering to right-wing and conservative political ideologies, as well as individuals over-emphasizing the importance of national identity, often adopt harsh and negative 
attitudes towards refugees (Chandler and Tsai 2001; Jones et al. 2016; Semyonov et al. 2006; Short 2004).

Without a doubt, patriotism is the most significant predictor of political affiliation (Depuiset and Butera 2005a). In its most general sense, the construct is defined as group members' undying commitment to their own group (Bar-Tal and Staub 1997). Patriotism enables characteristics indispensable for a group, or indeed an entire nation, by prompting and facilitating cohesion, integrity, and within-group mobility. Importantly, it generates a collective identity; a sense of both belonging and commitment (Bar-Tal 1993; Bar-Tal and Staub 1997). Schatz et al. (1999), however, demonstrated that there is a multi-dimensional structure to patriotism. They differentiated between blind patriotism and constructive patriotism. The difference between the two is related to the nature of commitment. Blind patriotism is characterized by uncritically accepting the policies and actions of one's country; a firm loyalty and a thriving intolerance. Constructive patriotism, on the other hand, is rather characterized by critical loyalty, which represents a commitment to one's country but with a maintained critical attitude. It allows for questioning policies and actions with a purpose of achieving positive change. Such change is called for when something threatens the basic values of society, general human values, or threatens that which is in the general interest of everyone (Schatz and Staub 1997; Schatz et al. 1999). Blind patriotism tends to correlate positively with tradition and negatively with universalism. Constructive patriotism, in contrast, does the exact opposite. It correlates negatively with tradition and positively with universalism (Livi et al. 2014).

One would expect to find blind patriotism in rigidly conservative groups set on safeguarding a political status quo. Importantly, such groups resist change. They usually ignore everything and everyone failing to be of interest to their own ranks and stated objectives. Groups more inclined towards constructive patriotism do the opposite. They will be concerned with issues which are not of interest to themselves only. They do this if the general welfare of everyone is at risk (Depuiset and Butera 2005a). The research field uses a number of different labels to describe these social phenomena, but they all tend to be similar to blind patriotism as well as constructive patriotism. For this reason, they could reasonably be categorized as either blind or constructive patriotism for the sake of clarity (e.g., Blank and Schmidt 2003; Blank et al. 2001; Schatz et al. 1999).

Studies pursued in other countries than Turkey have found that blind patriotism is likely to predict negative attitudes towards foreigners such as refugees. Research has also demonstrated a positive correlation between blind (or militant) patriotism and conservatism as well as xenophobia (Parker 2010; Schatz and Staub 1997; Schatz et al. 1999). Correlations with multi-culturalism, immigration, and refugee support, however, were shown to be negative (Spry and Hornsey 2007). In one study, with a sample drawn from 31 different countries, defined as "highly globalized," Ariely (2012) found a similar pattern. There appeared to exist a negative correlation between constructive patriotism and xenophobia, but a positive one between blind patriotism and xenophobia.

When religiosity and attitudes towards immigration are added to this context complexity increases. For example, ethnic prejudice has been shown to surprisingly correlate positively with religiosity in Europe. One would perhaps have expected the opposite given the professed charitable ethos of most European religious traditions. But research has shown that both Catholics and Protestants were likely to act with more prejudice towards ethnic majorities than European non-religious groups (Scheepers et al. 2002). In one American study, non-religious individuals, adherents to nonChristian faiths as well as non-white Christians, were all found to have a positive attitude towards refugees. But white Christians surprisingly adopted a more indecisive stance (Jones et al. 2016). Adding further to complexity there is also a difference between generations. While the younger generations of Protestant Christians are largely positive, the older generations are often more negatively inclined (Jones et al. 2016). Perhaps, as suggested by Storm (2011), who studied the relationship between religious affiliation and immigration attitudes in England, Holland, Ireland, and Denmark, when religiosity becomes an intrinsic part of one's ethnic identity by socialization, the likelihood of perceiving refugees as a threat to national identity increases considerably. Note that going to church regularly increased interest in, or perhaps reawakened, the more charitable aspects of European religious tradition. This, in turn, prompted increased tolerance (Billiet 1995; Eisinga et al. 1990).

It would have been reasonable to account for the relationship between refugee attitudes and the values of Islam in this context. To our knowledge, however, there are no such studies published. On the other hand, Islam, like Christianity and other faiths, tend to promote charity as an important value for all to strive for and uphold (e.g., Smither and Khorzandi 2009). Under normal circumstances charity as well as prosocial behavior are intrinsic values to the world's largest religions (Habito and Inaba 2006). The reason, we suggest, is that spirituality, however defined, is a recognized universal human behavior. The same is true of altruism, generosity, and hospitality (Brown 1991). For the current study, therefore, we have assumed that attitude formation in regard to refugees is likely to be similar in both Christian and Muslim contexts.

As far as Turkey is concerned, the number of studies focusing on refugees and the attitudes towards them are few. But they are increasing in numbers. They tend to focus on either Syrian students at Turkish universities or on Syrian children in Turkish state schools (e.g. Coșkun and Emin 2016; Erdem 2017; Karaoğlu 2015; Kılcan et al. 2017). Only a limited 
number of studies more generally focus on attitudes towards refugees (Doğan et al. 2017; Kılcan et al. 2017; Kiratlı 2011; Sağlam and Kanbur 2017; Sevi et al. 2016). These studies are, in turn, devoted to developing measuring instruments rather than focusing on attitudes directly. As far as we are aware, there is only one study available with such a focus. The result of this single study showed that factually correct information about refugees communicated to locals correlated positively with the attitudes towards them (Sevi et al. 2016).

Based on available published research and also based on the premise that understanding negative attitudes towards refugees is an important objective in developing suitable policies aimed at facilitating the reception of refugees, the objective of this research was to study how, and to what extent, such negative attitudes are related to age, patriotism, empathy, and nationalism/conservativism. Our assumption was that religious affiliation, empathy, and constructive patriotism, would predict positive attitudes while age, blind patriotism as well as nationalism/ conservatism, would rather predict negative attitudes.

\section{Methodology}

\section{Sample Description}

The sample for this study consisted of 457 university students in total, 252 of whom were female (\% 55.1) and 205 were male (\% 44.9); all studying in different departments at Cumhuriyet University at the city of Sivas in Turkey. Participants were between 18 and 21 years of age $(M=21$, $S D=1.82)$. Of the participants $431(94.3 \%)$ identified with Islam, one with $(0.2 \%)$ Judaism, six $(1.3 \%)$ stated they were Atheists, 14 (3.1\%) identified with Deism, and the remaining five $(1.1 \%)$ selected the "other" option of the administered questionnaire. In terms of political views, $176(38.5 \%)$ described themselves as nationalist/ conservative, $13(2.8 \%)$ as liberal, $70(15.3 \%)$ as centerright, $26(5.7 \%)$ as socialist/communist, $60(13.1 \%)$ as social democrat, and $24(5.3 \%)$ as belonging to the politically center-left, while $60(13.1 \%)$ participants reported to be undecided. Twenty-eight participants $(6.1 \%)$ decided not to answer the question at all. Also, 114 (24.9\%) were reasonably acquainted with refugees and their situation in Turkey, whereas $343(75.1 \%)$ reported that they were not.

\section{Data Collection Instruments}

Attitude Scale Towards Refugees (ASTR) The original scale was developed in Turkish by Doğan et al. (2017) to specifically identify attitudes towards refugees. It consists of one single factor defined by 28 items and shows good internal consistency. Each item was assessed by a five-point Likert scale (from 1 signifying complete disagreement to 5 expressing full agreement). As an example, translated into English, one of the scale items was this one: "I think that financial resources allocated to refugees are a waste". To prevent response bias six items of the scale were reverse coded. The higher the scoring the more negative the attitudes towards refugees. Lower scores reflected more positive attitudes. The shorter version of the scale, consisting of 16 items, was used for the first time in this study. Its internal consistency was acceptable $(\alpha=.94)$.

The Patriotism Attitude Scale (PAS) This scale was developed by Schatz et al. (1999) to measure feelings of patriotism among students. It consists of 20 items in total. The original version has two sub-scales: Blind patriotism and Constructive patriotism. A five-point Likert scale is used also in this instrument to assess to what degree each respondent agrees or disagrees. Internal consistency is reasonable for the Blind patriotism scale. It is lower, but still acceptable, for the Constructive patriotism scale. A Turkish adaptation of the scale was carried out by Yazıcı and Yazıcı (2010) resulting in a 17-item scale. Three of the original items were eliminated in the adapted version. This procedure slightly improved the internal consistency of one scale but also lessened the consistency of the other. A sample item from the adapted Turkish Blind Patriotism Scale, translated back into English to demonstrate the nature of the adaptation is, for example, the following: "People who do not support Turkey wholeheartedly should live somewhere else." As for the Constructive patriotism scale one sample item is this one: "If I criticize the Turkish Republic, I do this because of my love for the country." The internal consistency for both scales in its Turkish adapted form remained acceptable. Internal consistency was calculated also for the current sample of students demonstrating a slightly improved consistency for all three measures: Blind patriotism $(\alpha=.84)$, Constructive patriotism $(\alpha=.82)$, and for both scales together $(\alpha=.81)$.

Interpersonal Reactivity Index (IRI) Davis (1983) developed an instrument by which to measure the degree of empathy and sensitivity to the feelings of others. This instrument was chosen as a suitable measure. The original scale consisted of three sub-scales: Empathy, Taking the perspective of others, and Personal concern. Each of these consisted of seven items. A five-point Likert scale is used also for this instrument allowing respondents to assess their degree of agreement or disagreement with each statement. A Turkish adaptation exists for two of the three subscales by Kumru et al. (2004), namely for Empathy, and Taking the perspective of others. The internal consistency of the two scales improved to acceptable levels when employed in the current study: Empathy $(\alpha=.79)$, Taking the perspectives of others $(\alpha=.67)$, and for the two scales together $(\alpha=.82)$. One example item from the 
Empathy scale is this one: "I want to provide help when I see someone who is being scolded or ridiculed." An example also from the Taking the perspective of others scale would be the following: "I try to see the things from the perspective of each party before making a decision about a conflict".

Religiousness Scale (RS) A scale assessing levels of religiousness was developed by Cirhinlioğlu et al. (2016). It consists of 13 items rated by five-point Likert scales ranging from almost never (1) to almost always (5). The higher the scores of an individual assessed by the instrument, the higher their level of religious adherence. A sample item would be the following: "I often pray." Internal consistency for the current research sample was adequate $(\alpha=.90)$.

\section{Administration and Ethics}

Participants of this study were all students at different departments of Cumhuriyet University, Turkey. They were culled by snowball sampling. Prior to collecting data participants were duly informed about the aims of the research. We emphasized strongly that their participation was voluntary. They were given assurances of complete anonymity if deciding to participate. Administering the data collection instruments took approximately $30 \mathrm{~min}$.

\section{Manner of Analysis}

An independent sample $t$-test was employed to determine differences in response patterns between men and women. A predictor variable was then obtained through dummy coding on the basis of responses to "What is your political view" as well as on other variables. A Stepwise Regression Analysis was subsequently employed to determine which of the predictor variables made a statistically significant contribution in predicting attitudes towards refugees. Our chosen manner of analysis is a model-building one rather than a model-testing one (Tabachnick and Fidell 2001). This is an appropriate choice for an explorative study like ours. There are of course a number of different strategies for selecting variables for a regression model. For this study, however, a stepwise selection was used, which is a combination of both forward and backward selection technique.

\section{Results}

\section{Gender Differences}

An independent samples $t$-test analysis of participant groups was performed to determine whether the obtained scores differed between genders (Table 1). A significant difference was found. Men scored higher than women did regarding their
Table 1 Descriptive statistics for scores obtained from the Attitude Scale Towards Refugees divided into scores for men and women respectively $(N=457)$

\begin{tabular}{lllllll}
\hline & $N$ & $M$ & $S D$ & $t$ & $p$ & $d_{\text {Cohen }}$ \\
\hline Women & 252 & 2.48 & .77 & -2.37 & $.018^{*}$ & 0.22 \\
Men & 205 & 2.66 & .90 & & & \\
\hline
\end{tabular}

$* p<.01$

attitudes towards refugees. Hence, the men participating in this study adopted a more negative attitude than women did.

\section{Predicting Attitude Towards Refugees}

In employing a stepwise regression analysis, the Empathy variable showed the highest correlation with the dependent variable. It predicted the Attitude towards refugees variable negatively at the first stage $(\beta=-.38, p<.001)$. At the second stage, however, The Blind patriotism variable predicted Attitude towards refugees positively $(\beta=.29, p<.001)$, whereas in the third stage Religiousness predicted Attitude towards refugees positively $(\beta=.22, p<.001)$. Finally, in the fourth stage of the analysis the Nationalist/Conservative variable predicted Attitude towards refugees positively $(\beta=.28, p<.001)$. Table 2 shows the Pearson correlation coefficients between the different measured variables.

Age, Taking the perspective of others, and Constructive patriotism did not make any statistically significant contribution to predicting the dependent variable. While Empathy accounted for $7 \%$ of the variance, variance increased to $14 \%$ as the Blind patriotism variable was added to the model. When also Religiosity was added variance increased further to account for $18 \%$. Finally adding he Nationalist/Conservative variable to the model variance increased to $21 \%$. Thus, the higher the level of empathy, the lower the level of negative Attitude towards refugees. And the higher the Blind patriotism, Religiosity, as well as Nationalism/Conservatism levels, the higher also the level of negative Attitudes towards refugees (Table 3).

\section{Discussion}

This exploratory research aimed to study whether or not Turkish university students' age, empathy, nationalism/conservatism, patriotism, and religiosity could predict negative attitudes towards Syrian refugees. Results showed that men tend to be more negative towards refugees than women are. This finding is also consistent with previous research (e.g., Hernes and Knudsen 1992; Short 2004). One possible reason for the outcome, taking culture into account, is that differences are related to learned gender roles. Men in Turkey are inclined to uphold conservative traditions and see themselves as the 
Table 2 Pearson correlation coefficients between variables $(N=457)$

\begin{tabular}{lllllllll}
\hline & 1 & 2 & 3 & 4 & 5 & 6 & 7 & 8 \\
\hline Attitudes towards refugees & 1 & & & & & & \\
Religiosity & $.18^{* *}$ & 1 & & & & & & \\
Empathy & $-.26^{* *}$ & $-.24^{* *}$ & 1 & & & & \\
Perspective Tacking & $-.24^{* *}$ & $-.19^{* *}$ & $.51^{* *}$ & 1 & & & \\
Blind Patriotism & $.23^{* *}$ & $-.30^{* *}$ & $.11^{* *}$ & -.06 & 1 & & \\
Constructive Patriotism & -.04 & $-.15^{* *}$ & $.37^{* *}$ & $.24^{* *}$ & .08 & 1 & \\
Nationalist/conservative-other & $.23^{* *}$ & $-.11^{*}$ & -.02 & $-.11^{*}$ & $.29^{* *}$ & .02 & 1 \\
Age & -.05 & .08 & .03 & .08 & $-.14^{* *}$ & -.05 & -.02 & 1 \\
\hline
\end{tabular}

$* p<.05 ; * * p<.01$

primary breadwinner of their family. As such, when they look for work away from home they may perceive refugees as rivals in finding available work. This may prompt some men to construe refugees differently than women do.

Immigration has been also been shown to affect men and women in different ways and prompt changes in the gender role relationship (Hernes and Knudsen 1992). When facing increasing numbers of professionally qualified refugees, some men may perceive themselves as less attractive to women. Their chances of acquiring a decent job, they believe, could lessen because of construing well-educated refugees as potential rivals (cf., Puts et al. 2016; Sugiyama 2016). This gender-related perception could be understood as relative deprivation, which could explain that men are more prejudiced towards refugees than women are. However, causality is more complex than this. Storm (2011) found the same gender pattern in response to immigration in Denmark and Holland. But it was surprisingly not observed in England or Ireland. Since the findings of published research tend to be inconsistent it would be unwise to generalize our own results regarding gender differences in attitudes towards refugees. Fur future research it would be of interest to include demographic variables as moderator variables such as age, educational level and income, to possibly determine which variables would generate more consistent results. Thus, there is a need for more comprehensive research to determine whether gender differences do exist in the cultural setting of the current study.

The stepwise regression analysis demonstrated that Empathy was an important predictor of attitudes towards refugees. The same was true of Blind patriotism, Religiosity, and being a Nationalist/Conservative. However, Age, Taking the perspective of others, and Constructive patriotism did not appear to predict attitudes towards refugees.

Our research demonstrated that when negative attitudes decreased the level of empathy increased. A number of published studies have suggested that the feeling of empathy triggers an incentive to help others (Eisenberg et al. 2010; Eisenberg \& Fabes, 1998; Murphy at el. 1999). Individuals scoring high levels of empathy are also likely to act because of their empathy (Betancourt 1990; Davis 1994; Dovidio et al. 2010). Of importance to the current study is that the feeling of empathy tends to lead to more positive attitudes towards ethnic minorities encountering both discrimination and injustices (Stephan and Finlay 1999). Syrian refugees arriving to the Sivas Province in Turkey exist under relatively difficult conditions. In addition, they carry with them a terrible burden of war and conflict. There are many reasons, therefore, to trigger feelings of empathy in others. We found that this was indeed the case. Students in the research sample with high levels of empathy also demonstrated feelings of empathy towards
Table 3 Results of the stepwise regression analysis $(\mathrm{N}=457)$

\begin{tabular}{rlllllll}
\hline Model & Predictors & $R^{2}$ & $F$ & $p$ & $\beta$ & \multicolumn{1}{l}{$t$} & \multicolumn{1}{l}{$p$} \\
\hline 1 & Empathy & .07 & 34.08 & .001 & -.38 & -5.84 & .000 \\
2 & Empathy & .14 & 36.82 & .001 & -.43 & -6.69 & .000 \\
& Blind patriotism & & & & .29 & 6.07 & .000 \\
3 & Empathy & .18 & 33.68 & .001 & -.36 & -5.62 & .000 \\
& Blind patriotism & & & & .35 & 7.36 & .000 \\
& Religiosity & & & & .22 & 4.87 & .000 \\
& Empathy & .21 & 29.51 & .001 & -.34 & -5.47 & .000 \\
& Blind patriotism & & & & .30 & 6.13 & .000 \\
& Religiosity Total & & & & .22 & 5.06 & .000 \\
& Nationalist/conservative-other & & & & .28 & 3.76 & .000 \\
& & & & & & &
\end{tabular}


the exiled Syrians in the Sivas Province. However, empathy is a multi-dimensional construct (Cuff et al. 2014; Davis 1994; Smith 2006). A distinction is often made between the learned skill to take the perspective of others (cognitive empathy) and the ability of sharing another's feelings (emotional empathy). In our study, helping others as well as the skill of taking the perspective of othersboth defining a more cognitive dimension of social behavior-did not correlate with a positive attitude towards the refugees. For this reason, we suggest that participants in general were more oriented towards emotional empathy.

The fact that this study found no statistically significant relationship between age and attitudes towards refugees is partly in line with published research (e.g., Short 2004). Some studies have suggested that individuals between 30 and 40 years of age are more positive towards refugees, while the younger generation (younger than 20), and also individuals aged 50 or more, tend to adopt a more negative attitude (Hernes and Knudsen 1992). Some studies have also concluded, more generally, that age and negative attitudes towards refugees correlate positively (Bentsen 2017; Bloom 2011; Gorodzeisky and Semyonov 2009). The results of the current study should therefore be interpreted with some caution. Our participants were between 18 to 27 years of age $(M=21)$. Further research is needed to establish whether or not age is a determinant factor in this context.

Similarly, religiosity predicted negative attitudes towards refugees positively. This, too, is consistent with previous studies (Coenders and Scheepers 2003; Jones et al. 2016; Scheepers et al. 2002). One possible explanation for these results is that participating students placed more emphasis on the social and humanistic aspects of the obvious plight of refugees rather than on the doctrines and traditions of their professed religion. Religion tends to constitute an important part of cultural identity (Storm 2011). Our findings, however, nevertheless need cautious interpretation here as well. We do not know how religion was construed by participants and why (see Hainmueller and Hiscox 2007; Jones et al. 2016). Specific research is needed to untangle the influences of religion on attitudes towards refugees.

As far as individuals professing nationalist/conservative ideals or perceive themselves as blind patriots, are concerned, they adopted a mainly negative attitude. This also agrees with already published research (Chandler and Tsai 2001; Espenshade and Hempstead 1996; Jones et al. 2016; Short 2004; Semyonov et al. 2006). While constructive patriots are often positive (Blank and Schmidt 2003), individuals with no or limited education tend to be oriented towards the political right. They embrace a more patriotic view and, as a result, often regard refugees as a threat no matter what (Raijman et al. 2008). Blind patriotism is related to authoritarianism characterized by a tendency to show respect and provide unconditional support to figures of authority. Authoritarians, not surprisingly, are therefore inclined to be more conservative. In consequence, blind patriotism is often to be found among the politically conservative (Schatz et al. 1999). A number of studies have found a relationship between conservatism and xenophobia thus predicting negative attitudes towards refugees also (Ariely 2012; Parker 2010; Schatz and Staub 1997; Schatz et al. 1999; Spry and Hornsey 2007). When empathy and positive social values correlate positively with constructive patriotism, but are simultaneously related negatively to blind patriotism, also blind patriots are likely to adopt negative attitudes. When emotional empathy together with positive social values correlate positively with constructive patriotism, and simultaneously correlates negatively with blind patriotism, blind patriots still adopt a negative attitude towards refugees (Depuiset and Butera 2005b; see also Schatz 1995). In the current study, blind patriotism predicted attitudes towards refugees, but constructive patriotism did not. This outcome can most likely be explained by participant characteristics. Most students at Cumhuriyet University, located in the relatively conservative Sivas province, have grown up in smaller towns and communities rather than in larger and more cosmopolitan cities. It is a fair assumption that local conservatism has affected also the current sample and their general outlook on life. If so, an emphasis on blind patriotism is to be expected. This assumption has some culturally appropriate and empirical support (Ercan 2017).

Finally, empathy, blind patriotism, religiosity, and nationalist/conservative views, respectively, were all found to correlate significantly with some discriminatory attitudes. In addition, the feeling of empathy was observed to predict attitudes towards refugees negatively while blind patriotism, religiosity, and nationalist/conservative views, predicted attitudes towards refugees positively.

\section{Research Results and What they Suggest}

Based on the results of the current exploratory study, albeit tentative, they nevertheless suggest the value of training programs aiming to engage participants in activities which would enable them to learn to develop empathy. Individuals scoring high on both conservatism and religiosity would present a particular challenge. More than anything these individuals would need to be made aware of the values that they uncritically hold on to; values which they probably have adopted without much personal reflection. They need to understand what potential consequences rigid and unconsidered attitudes might have.

To raise awareness and encourage reflection such a training program will need to include interaction with individuals from a variety of cultures. It will also need to focus on the societal values of equality and respect. The use of appropriate religious texts emphasizing these values would be important in 
establishing general legitimacy of such a program, and also to make it more attractive to a largely conservative population.

\section{Research Limitations}

While this research succeeded in demonstrating the significance of feeling empathy, blind patriotism, religiosity, and nationalist/conservative adherence in predicting negative attitudes towards refugees, there are also limitations to be considered in understanding the research results.

Firstly, this study relied on a cross-sectional design making it more difficult to consider cause, effect, and the direction of studied behaviors. A more appropriate design would have been a proper longitudinal study.

The research group of only students is another limitation due to their relatively young age. Attitudes towards refugees are known to vary depending on whether an individual is older or younger. To study age as a factor in explaining how and why attitudes develop a sample of different age groups is necessary.

Different levels of education were also not considered. All participants were university students and shared both the same education level and a narrow age range (18-21 years of age).

The location of the study may also be of some concern. The Sivas Province, together with its capital city of Sivas, is a relatively conservative part of Turkey. It would have been an advantage to sample participants more widely and from additional regions in Turkey allowing for a more heterogenous sample and a more reliable generalization.

In conclusion, this study collected data by means of a paper-and-pencil questionnaire. Self-reporting will always present a challenge in terms of reliability. Future research needs to consider additional data collection methods among which observations and interviews over a longer period of time would be the most suitable. These would help avoid, or at least minimize, possible response biases. As with all current research, however, chosen methods, sampling, and the nature of posed research questions, are all subject to time and budget constraints. These are always an integral part of planning any research effort. Choices made on how to operationalize any study are therefore always the result of some compromise.

Open Access This article is distributed under the terms of the Creative Commons Attribution 4.0 International License (http:// creativecommons.org/licenses/by/4.0/), which permits unrestricted use, distribution, and reproduction in any medium, provided you give appropriate credit to the original author(s) and the source, provide a link to the Creative Commons license, and indicate if changes were made.

\section{References}

Aktaș, V., \& Persson, R. S. (2017). Fel person på fel plats [The wrong individual in the wrong place]. In H. Ahl, I. Bergmo-Prvulovic, \& K. Kilhammar (Eds.), HR: Att ta tillvara mänskliga resurser (pp. 191206). Lund: Studentlitteratur AB.
Anderson, C. A., Shibuya, A., Ihori, N., Swing, E. L., Bushman, B. J., Sakamoto, A., \& Saleem, M. (2010). Violent video game effects on aggression, empathy, and prosocial behavior in eastern and western countries: A meta-analytic review. Psychological Bulletin, 136(2), 151-173. https://doi.org/10.1037/a0018251.

Ariely, G. (2012). Globalization, immigration and national identity: How the level of globalization affects the relations between nationalism, constructive patriotism and attitudes toward immigrants? Group Processes \& Intergroup Relations, 15(4), 539-557. https://doi.org/ $10.1177 / 1368430211430518$.

Bar-Tal, D. (1993). Patriotism as fundamental beliefs of group members. Politics and the Individual, 3, 45-63.

Bar-Tal, D., \& Staub, E. (1997). Introduction: Patriotism: Its scope and meaning. In D. Bar-Tal \& E. Staub (Eds.), Patriotism: In the lives of individuals and nations (pp. 1-21). Chicago: Nelson-Hall.

Bentsen, B.M.A. (2017). Attitudes toward Immigrants among Youth in Sweden WelfareWorking Paper Series (No. 17:4). Malmö Institute for Studies of Migration, Diversity and Welfare, Malmö University, Sweden. Available at https://www.mah.se [Retrieved 27 May 2018].

Betancourt, H. (1990). An attribution-empathy model of helping behavior: Behavioral intentions and judgments of help-giving. Personality and Social Psychology Bulletin, 16(3), 573-591. https://doi.org/10. 1177/0146167290163015.

Billiet, J. B. (1995). Church involvement, individualism, and ethnic prejudice among Flemish roman Catholics: New evidence of a moderating effect. Journal for the Scientific Study of Religion, 34, 224-233.

Blank, T., \& Schmidt, P. (2003). National identity in a united Germany: Nationalism or patriotism? An empirical test with representative data. Political Psychology, 24(2), 289-312.

Blank, T., Schmidt, P. \& Westle, B. (2001). Patriotism-A contradiction, a possibility, or an empirical reality? Paper presented at the ECPR Workshop 26, National Identity in Europe, Grenoble, France.

Bloom, S. (2011). Attitudes towards immigrants and immigration. In K. Henriksen, L. Østby, \& D. Ellingsen (Eds.), Immigration and immigrants (pp. 133-147). Oslo: Statistics Norway.

Bodvarsson, Ö. B., \& Van den Berg, H. (2013). The Economics of Migration: Theory and Policy ( $2^{\text {nd }}$ ed.). Dordrecht: Springer.

Brown, D. E. (1991). Human universals. New York: McGraw-Hill.

Bunar, N. (2007). Hate crimes against immigrants in Sweden and community responses. American Behavioral Scientist, 51(2), 166-181.

Carreras, M. R., Braza, P., Muñoz, J. M., Braza, F., Azurmendi, A., Pascual Sagastizabal, E., Cardas, J., \& Sánchez Martín, J. R. (2014). Aggression and prosocial behaviors in social conflicts mediating the influence of cold social intelligence and affective empathy on children's social preference. Scandinavian Journal of Psychology, 55(4), 371-379.

Chandler, C. R., \& Tsai, Y. M. (2001). Social factors influencing immigration attitudes: An analysis of data from the general social survey. The Social Science Journal, 38(2), 177-188. https://doi.org/10. 1016/S0362-3319(01)00106-9.

Cirhinlioğlu, F., Cirhinlioğlu, Z., \& Kındap-Tepe, Y. (2016). The mediating role of religiousness in the relationship between the attachment style and marital quality. Current Psychology, 37, 207-215. https:// doi.org/10.1007/s12144-016-9504-5.

Coenders, M., \& Scheepers, P. (2003). The effect of education on nationalism and ethnic exclusionism: An international comparison. Political Psychology, 24, 313-343.

Coşkun, İ. \& Emin, M. N. (2016). Türkiye'deki Suriyelilerin eğitimde yol haritas1. Firsatlar ve zorluklar [A road map for the education of Syrians in Turkey. Opportunities and challenges]. SETA Siyaset, Ekonomi ve Toplum Araștırmaları Vakfi: İstanbul. http://file.setav. org [Retrieved 7 August 2016].

Cuff, B. M. P., Brown, S. J., Taylor, L., \& Howat, D. J. (2014). Empathy: A review of the concept. Emotion Review, 8, 144-153. https://doi. org/10.1177/1754073914558466. 
Davis, M. H. (1983). Measuring individual differences in empathy: Evidence for a multidimensional approach. Journal of Personality and Social Psychology, 44(1), 113-126.

Davis, M. H. (1994). Empathy: A social psychological approach. Madison: Brown and Benchmark.

De los Reyes, P. (2008). Etnisk diskriminering $i$ arbetslivet: Kunskapsläge och kunskapsbehov [Ethnic discrimination at work: State and need of current knowledge]. Stockholm: Landsorganisationen i Sverige.

Deniz, T. (2014). Uluslararası göç sorunu perspektifinden Türkiye. [international migration issues from the perspective of Turkey]. Türkiye Sosyal Araştırmalar Dergisi, 18(1), 175-204.

Depuiset, M. A., \& Butera, F. (2005a). On the relevance of studying patriotism and normative conflict in changing attitudes towards immigrants. Psicología Política, 30, 71-84.

Depuiset, M. A., \& Butera, F. (2005b). The stability of patriotism in the face of variation in national laws. Psychologica Belgica, 43(1/2), 123-138.

Doğan, M., Erdoğan, S., Yunus, S., \& Kindap Tepe, Y. (2017). Mültecilere Yönelik Tutum Ölçeği Geliştirme Çalıșması. In L. Aydemir (Ed.), Uluslararası Sosyal ve Beşeri Bilimler Berlin Konferanst, Sosyal ve Beşeri Bilimler Araştırmaları tam metin kitapçı̆̆l içinde [Proceedings of the International Conference on Social and Human Sciences in Berlin, DE]. Trabzon: Karadeniz Teknik Üniversitesi Yayınları.

Dovidio, J. F., Johnson, J. D., Gaertner, S. L., Pearson, A. R., Saguy, T., \& Ashburn-Nardo, L. (2010). Empathy and intergroup relations. In M. Mikulincer \& P. R. Shaver (Eds.), Prosocial motives, emotions, and behavior: The better angels of our nature (pp. 393-408). Washington, DC: American Psychological Association.

Eisenberg, N., \& Fabes, R. A. (1998). Prosocial development. In W. Damon \& N. Eisenberg (Eds.), Handbook of child psychology: Vol. 3. Social, emotional, and personality development (5th ed., pp. 701-778). New York: Wiley.

Eisenberg, N., Eggum, N. D., \& Giunta, L. D. (2010). Empathy-related responding: Associations with prosocial behavior, aggression, and intergroup relations. Social Issues Policy Review, 4, 143-180. https://doi.org/10.1111/j.1751-2409.2010.01020.x.

Eisinga, R., Felling, A., \& Peters, J. (1990). Religious belief, church involvement, and ethnocentrism in the Netherlands. Journal for the Scientific Study of Religion, 29(1), 54-75 https://doi.org/10. 2307/1387030.

Ercan, H. (2017). Self-construal and demographic variables as predictors of blind and constructive patriotism in university students. International Journal of Higher Education, 6(6), 170-179. https:// doi.org/10.5430/ijhe.v6n6p170.

Erdem, C. (2017). Sınıfında mülteci öğrenci bulunan sınıf öğretmenlerinin yaşadıkları öğretimsel sorunlar ve çözüme dair önerileri [instructional problems experienced by primary school teachers who have refugee students in their classes and their solutions for problems]. Medeniyet Eğitim Araştırmaları Dergisi, 1(1), 26-42.

Espenshade, T. J., \& Hempstead, K. (1996). Contemporary American attitudes toward U.S. immigration. International Migration Review, 30, 535-570.

European Commission (2017). Communication from the Commission to the European Parliament and the Council First Annual Report on the Facility for Refugees in Turkey, COM (2017/130), Brussels. https://ec.europa.eu/neighbourhood-enlargement [Retrieved 29 December 2017].

Girit, S. (2015). Güvercintepe: 'Suriyeliler gitsin, huzur kalmadı'. BBC Türkçe, İstanbul. http://www.bbc.com/turkce/haberler/ [Retrieved 7 January 2018].

Gorodzeisky, A., \& Semyonov, M. (2009). Terms of exclusion: Public views towards admission and allocation of rights to immigrants in European countries. Ethnic and Racial Studies, 32(3), 401-423.
Greitemeyer, T. (2011). Effects of prosocial media on social behavior: When and why does media exposure affect helping and aggression? Current Directions in Psychological Science, 20(4), 251-255.

Güneş, M. (2013). Uluslararası göçün tetikleyicileri: Suriye'den Türkiye'ye zorunlu göç'ün Cilvegözü örneği ile yansımaları. [What triggers international migration? The consequences of events at Cilvegözü] (Unpublished MA Thesis), Turgut Özal University, Institute of Social Sciences, Department of Political Science and International Relations.

Habito, R. L. F., \& Inaba, K. (Eds.). (2006). The practice of altruism: Caring and religion in global perspective. Cambridge, UK: Cambridge University Press.

Hagen-Zanker, J. (2008). Why do people migrate? A review of the theoretical literature. (Maastricht Graduate School of Governance Working Paper, No. 2008/WP002. Available at https://ssrn.com/ abstract=1105657 (Retrieved 03 December 2015).

Hainmueller, J., \& Hiscox, M. J. (2007). Educated preferences: Explaining attitudes toward immigration in Europe. International Organization, 61(2), 399-442.

Hernes, G., \& Knudsen, K. (1992). Norwegians' attitudes toward new immigrants. Acta Sociologica, 35(2), 123-139.

İçduygu, A., \& Aksel, D. B. (2012). Türkiye’de Düzensiz Göç [Irregular migration in Turkey]. Ankara: Uluslararası Göç Örgütü Türkiye.

Jolly, S. K., \& DiGiusto, G. M. (2014). Xenophobia and immigrant contact: French public attitudes toward immigration. The Social Science Journal, 51(3), 464-473. https://doi.org/10.1016/j. soscij.2013.09.018.

Jones, R. P, Cox, D., Cooper, B. \& Lienesch, R. (2016). How Americans view immigrants, and what they want from immigration reform: Findings from the 2015 American Atlas. Washington, DC: Public Religion Research Institute. https://www.prri.org/ [Retrieved 30 December 2017].

Karaoğlu, E. (2015). The Role of Social Dominance Orientatıon, Empathy And Percelved Threat In Predicting Prejudice Of Turkish Cittzens Toward Syrian Immigrants (Doctoral dissertation), Middle East Technical University, Ankara, Turkey.

Kılcan, B., Çepni, O., \& Kılınç, A. Ç. (2017). Mülteci öğrencilere yönelik tutum ölçeğinin geliștirilmesi [Development of the attitude towards refugee students scale]. Journal of Human Sciences, 14(2), 10451057. https://doi.org/10.14687/jhs.v14i2.4324.

Kıratlı, T. (2011). Mülteci ve sığınmacıların toplumsal görünümü (Türkiye Örneği) [Social aspects of refugees and asylum seekers: The case of Turkey] (Unpublished MA Thesis), Süleyman Demirel University, Institute of Social Sciences, Isparta, Turkey.

Kumru, A., Carlo, G., \& Edwards, C.P. (2004) Olumlu Sosyal Davranıșların İlișkisel, Kültürel, Bilișsel ve Duyușsal Bazı Değişkenlerle İlişkisi Türk Psikoloji Dergisi, 19 (54), 109-125.

Lemaitre, G. (2007). The integration of immigrants into the labour market: The case of Sweden (OECD Social, Employment and Migration Working Papers, No. 48). Paris, FR: OECD Publishing.

Livi, S., Leone, L., Falgares, G., \& Lombardo, F. (2014). Values, ideological attitudes and patriotism. Personality and Individual Differences, 64, 141-146.

Lohrmann, R. (2003). Migrants, refugees and insecurity. Current threats to peace? International Migration, 38(4), 3-22.

Murphy, B. C., Shepard, S. A., Eisenberg, N., Fabes, R. A., \& Guthrie, I. K. (1999). Contemporaneous and longitudinal relations of dispositional sympathy to emotionality, regulation, and social functioning. The Journal of Early Adolescence, 19(1), 66-97.

Newman, B., Hartman, T., Lown, P., \& Feldman, S. (2015). Easing the heavy hand: Humanitarian concern, empathy, and opinion on immigration. British Journal of Political Science, 45(3), 583-607. https:// doi.org/10.1017/S0007123413000410.

Paas, T., \& Halapuu, V. (2012). Attitudes towards immigrants and the integration of ethnically diverse societies. Eastern Journal of European Studies, 3(2), 161-176. 
Parker, C. S. (2010). Symbolic versus blind patriotism: Distinction without difference? Political Research Quarterly, 63(1), 97-114.

Puts, D. A., Bailey, D. H., \& Reno, P. L. (2016). Contest competition in men. In D. M. Buss (Ed.), The handbook of evolutionary psychology (2 $2^{\text {nd }}$ Ed.). Volume one: Foundations (pp. 385402). Hoboken: Wiley.

Raijman, R., Davidov, E., Schmidt, P., \& Hochman, O. (2008). What does a nation owe non-citizens? National attachments, perception of threat and attitudes toward granting citizenship rights in comparative perspective. International Journal of Comparative Sociology, 49(2-3), 195-220. https://doi.org/10.1177/0020715208088912.

Rydgren, J. (2004). Mechanisms of exclusion: Ethnic discrimination in the Swedish labour market. Journal of Ethnic and Migration Studies, 30(4), 697-716.

Sağlam, H. İ., \& Kanbur, N. İ. (2017). Sınıf Öğretmenlerinin Mülteci Öğrencilere Yönelik Tutumlarının Çeșitli Değișkenler Açısından İncelenmesi [Investigation Attitudes towards Refugee Students of Class Teachers' in Terms of Several Variables]. Sakarya University Journal of Education, 7(2), 310-323.

Schatz, R. T. (1995). On being a good American: Blind versus constructive patriotism. Unpublished Dissertation Abstracts International, University of Massachusetts, MA, Amherst.

Schatz, R. T., \& Staub, E. (1997). Manifestations of blind and constructive patriotism: Personality correlates and individual-group relations. In D. Bar-Tal \& E. Staub (Eds.), Patriotism: In the lives of individuals and nations (pp. 229-245). Chicago: Nelson-Hall.

Schatz, R., Staub, E., \& Lavine, H. (1999). On the varieties of national attachment: Blind versus constructive patriotism. Political Psychology, 20, 154-174.

Scheepers, P., Gijsberts, M., \& Hello, E. (2002). Religiosity and prejudice against ethnic minorities in Europe: Cross-national tests on a controversial relationship. Review of Religious Research, 43(3), 242-265.

Semyonov, M., Raijman, R., \& Gorodzeisky, A. (2006). The rise of antiforeigner sentiment in European societies, 1988-2000. American Sociological Review, 71, 426-449.

Sevi, B., Arala, T. \& Aydınl-Karakulak, A. (2016). Mültecilere karşı tutumları açıklayan etkenler: Algılanan hastalıklara açı olma değeri ve bilgi düzeyi [Factors explaining the attitudes towards refugees: Perceived vulnerability to disease and knowledge level]. Paper presented in I. Social Psychology Congress, Ankara, Turkey.

Short, R. R. (2004). Justice, politics, and prejudice regarding immigration attitudes. Current Research in Social Psychology, 9(14), 193-208.

Sirin, C. V., Valentino, N. A., \& Villalobos, J. D. (2016). Group empathy theory: The effect of group empathy on US intergroup attitudes and behavior in the context of immigration threats. Journal of Politics, 78(3), 893-908. https://doi.org/10.1086/685735.

Smith, A. (2006). Cognitive empathy and emotional empathy in human behavior and evolution. The Psychological Record, 56(1), 3-21.
Smither, R., \& Khorzandi, A. (2009). The implicit personality theory of Islam. Psychology of Religion and Spirituality, 1(2), 81-96.

Spry, C., \& Hornsey, M. (2007). The influence of blind and constructive patriotism on attitudes toward multiculturalism and immigration. Australian Journal of Psychology, 59(3), 15-158.

Stephan, W. G., \& Finlay, K. (1999). The role of empathy in improving intergroup relations. Journal of Social Issues, 55, 729-743. https:// doi.org/10.1111/0022-4537.00144.

Stephan, W. G., Ybarra, O., \& Bachman, G. (1999). Prejudice toward immigrants. Journal of Applied Social Psychology, 29(11), 22212237.

Storm, I. (2011). Christian nations? Ethnic christianity and antiimmigration attitudes in four Western European countries. Nordic Journal of Religion and Society, 24(1), 75-96.

Sugiyama, L. S. (2016). Physical attractiveness: An adaptionist perspective. In D. M. Buss (Ed.), The handbook of evolutionary psychology (2 ${ }^{\text {nd }}$ Ed.). Volume one: Foundations (pp. 317-384). Hoboken: Wiley.

Tabachnick, B. G., \& Fidell, L. S. (2001). Using multivariate statistics (4th ed.). Boston: Allyn and Bacon.

Tamura, A., \& Sugiura, Y. (2017). Prosocial behavior and physical aggression in psychopathy: Mediating effect of affective and cognitive empathy. The Japanese Journal of Personality, 26(1), 38-48.

Türkoğlu, O. (2011). Mülteciler Ulusal / Uluslararası Güvenlik [refugees and national/international security]. Uludağ Üniversitesi $\dot{I I B F}$ Dergisi, 30(2), 101-118.

UN High Commissioner for Refugees [UNHCR]. (2011). Handbook and Guidelines on Procedures and Criteria for Determining Refugee Status under the 1951 Convention and the 1967 Protocol Relating to the Status of Refugees. UN Doc HCR/1P/4/ENG/Rev. 3. Geneva. http://www.unhcr.org/3d58e13b4.html [Retrieved 25 July 2018].

United Nations High Commissioner for Refugees [UNHCR]. (2017). Global Trends: Forced Displacement in 2016. http://www. refworld.org [Retrieved 29 December 2017].

Verkuyten, M., Mepham, K., \& Kros, M. (2017). Public attitudes towards support for migrants: The importance of perceived voluntary and involuntary migration. Ethnic and Racial Studies, 41, 901-918. https://doi.org/10.1080/01419870.2017.1367021.

Wikipedia (2017). Mülteci. Erișim: https://tr.wikipedia.org/ [Retrieved 30 January 2017].

Yazıcı, S., \& Yazıcı, F. (2010). Yurtseverlik tutum ölçeğinin geçerlilik ve güvenilirlik çalıșması [A study of the validity and reliability of the patriotism attitude scale]. Uluslararasi Insan Bilimleri Dergisi, 7(2), 901-918.

Yolcu, M. (2014). Kahramanmaraș'ta 'Suriyelileri istemiyoruz' yürüyüșünde olaylar çıktı [In one recent demonstration in Kahramanmaras, city in southeast Turkey, demonstrators chanting, "We do not want Syrians!" attacked Syrian refugees]. HürriyetGündem haberleri. http://www.hurriyet.com.tr/ [Retrieved 7 January 2018]. 